\title{
PICKPOCKETING: A SURVEY OF THE CRIME AND ITS CONTROL
}

Pickpocketing traditionally has been one of the major law enforcement problems presented by large gatherings of people for sport events, carnivals, circuses, conventions and the like. It would be reasonable to assume that the pickpocket problem is becoming more acute as such gatherings increase in number, size and frequency due to improvements in transportation, increased population and growth of urban centers. Surprisingly, however, inquiry into the problems of detecting and convicting pickpockets which was made of police and other law enforcement officials of sixty-seven selected cities $^{1}$ indicated a general belief that the crime of pickpocketing is well under control. The manner in which this has been accomplished is an interesting example of the effectiveness of using statutes defining a general crime which cuts across the usual criminal classifications in order to stamp out a particular offense, but it also presents the question of the desirability of such procedure.

\section{Description of Pickpocketing}

Most pickpockets ${ }^{2}$ are professionals. ${ }^{3}$ Theirs is a lucrative ${ }^{4}$ and highly skilled art requiring unusual manual dexterity, ${ }^{5}$ knowledge of human behavior ${ }^{6}$ and precision teamwork. ${ }^{7}$ They often work in crowds, but can be just as successful with a lone victim. ${ }^{8}$ The chief characteristic of this

1. All letters and questionnaires which are hereinafter cited were received by the University of Pennsylvania Law Review in response to a survey undertaken in the preparation of this Note and are on file in Biddle Law Library, University of Pennsylvania Law School. The University of Pentrsylvania Laze Revieze wishes to express its appreciation for the cooperation, assistance, advice and information supplied by the law enforcement officials and prosecuting attorneys canvassed in the survey.

2. Pickpockets of the category being discussed here are to be distinguished from sneak thieves who snatch purses or steal articles from seats in movie houses and from the prostitutes who take a man's wallet while carressing him or who operate with a confederate who does the actual taking of the article. These criminals present problems entirely different from those presented by the transient, skilled, professional pickpocket.

3. Von Hentig, The Pickpocket: Psychology, Tactics and Technique, 34 J. CRrM. L., C. \& P.S. 11-15 (1943); Stearns, How Your Pocket May Be Picked, Readers' Digest, Dec. 1953 , p. 147.

4. See Martinez, Secrets of a Pickpocket Detective, Saturday Evening Post, Oct. 21, 1950, pp. 31, 159.

5. Gross, Criminat Investigation 512 (1924).

6. Stearns, supra note 3 .

7. Cavan, Crminology 143 (1948); Hapgood, The Autobiography of a Thuef 52 (1903).

8. Von Hentig, supra note 3, at 15; Pickins' Are Not So Good, Spring 3100, March 1951, p. 4 (N.Y. City Police Dep't publication). 
form of larceny is that the victim is entirely unaware of the theft while it is being perpetrated even though the theft is from his person. ${ }^{9}$ The thief is ordinarily well-dressed and of polite, respectable demeanor. ${ }^{10} \mathrm{He}$ conceals his movements by blocking the victim's view with a newspaper or coat, bumping into and jostling him, or operating while the victim's attention is focused on an external event like a parade, circus or horse race. Often a confederate will jostle a victim in order to locate in which pocket his wallet is carried. Sometimes the confederate will jostle the victim or start an argument with him while the pickpocket operates. Other accomplices act as shields to prevent the public or police officers from observing the actual theft. When the theft has been accomplished, the stolen articles are often passed immediately to an accomplice. If the police move toward a pickpocket who has not yet handed the stolen article to his confederate, the thief will drop the stolen article to the ground and, of course, deny everything. ${ }^{11}$

\section{Applicable Criminal Laws}

\section{Larceny}

This description of the crime makes it clear that pickpocketing is a form of larceny. To make a prima facie case of larceny there must be evidence of: (1) a taking, (2) of the personal goods of another, (3) with a felonious intent permanently to deprive the owner of its use. ${ }^{12}$ Although several cities reported successful larceny prosecutions and many indicated they would prefer to use the larceny statutes to control pickpocketing, it is generally conceded that larceny statutes are not effective for convicting pickpockets because of the stringent requirements of proof which they impose.

Occasionally the elements of the crime may be proved by the testimony of the victim or an eye witness who actually saw the taking and who can positively identify the accused as the one who did the act; ${ }^{13}$ this witness may be the detective who had been following the thief with the expectation that he would attempt to commit the crime. ${ }^{14}$ However, the operations of the skilled pickpocket include measures designed to insure that neither the victim nor any bystanders will be able to witness the actual taking of the property. ${ }^{15}$

9. Von Hentig, supra note 3 , at 15 .

10. Martinez, supra note 4 , at 158 .

11. Pickins' Are Not So Good, Spring 3100 March 1951, p. 4 (N.Y. City Police Dep't publication).

12. Claark \& Marshall, Crimes $\$ 305$ (5th ed. 1952).

13. See People v. Oberholdt, 359 Ill. 39, 193 N.E. 608 (1934) ; Adams v. Commonwealth, 153 Ky. 88, 154 S.W. 381 (1913); Commonwealth v. Luckis, 99 Mass. 431 (1868); McFarlin v. State, 122 Tex. Crim. 347, 55 S.W.2d 844 (1932); State v. Chambers, 22 W. Va. 779 (1883).

14. Telephone interview with Captain Richard T. Doyle, Philadelphia Police Force, Dec. 12, 1955. 1955.

15. Letter from O. C. Beynon, Inspector of Detectives, Tampa, Fla., Jan. 20, 
It is also possible that sufficient evidence to convict of larceny can be obtained if the thief is detected while he has his hand in his victim's pocket. A conviction for larceny can be sustained simply on the showing that the thief had grasped the wallet or some other property of the victim; the slightest movement of the article is deemed sufficient.16 Even if it cannot be shown that the accused had seized any article, ${ }^{17}$ or if it develops that the pocket was empty, ${ }^{18}$ it is nevertheless possible to convict him of an attempt to commit larceny. As a practical matter, however, it is extremely unlikely that a skilled professional pickpocket would be so clumsy or so slow that he is caught in the act of taking.

A third possible avenue to prosecution for larceny is through the detection of the defendant with the stolen property in his possession and without explanation of how it got there. ${ }^{19}$ If there is a showing that the defendant had jostled the victim, evidence that the accused had in one pocket the exact sum of money which the victim reported stolen, ${ }^{20}$ or evidence that the stolen article was on the street near the accused ${ }^{21}$ has been held to be adequate to prove circumstantially that this defendant committed the larceny. But again, as the description of the modus operandi of pickpockets would indicate, it is quite difficult to detect the crime before the property has been passed to a confederate who slips away into the crowd.

Consequently, the most likely occurrence is that the theft will be completed without detection, that thereafter the victim will discover that his property is gone and complain to the police. He will be unable to describe or even recognize the pickpocket; he may accuse the thief's accomplice who distracted his attention, but who, of course, does not have and probably never had possession of the stolen article. But as a rule, the victim will have no idea where, when or how the theft occurred. ${ }^{22}$

A further difficulty in gaining convictions for larceny even where suffcient proof is obtainable arises because pickpockets frequently operate at transportation terminals, parades, sports events, stores, and similar crowded spots. ${ }^{23}$ Since the victim is often only at the scene of the crime temporarily,

16. State v. Chambers, 22 W. Va. 779 (1883).

17. State v. Wilson, 30 Conn. 500 (1862) ; State v. Johnson, 78 Kan. 866, 98 Pac. 216 (1908).

18. People v. Moran, 123 N.Y. 254 (1890).

19. Wiggins v. State, 31 Ala App. 50,12 So. $2 d 758$ (1943) ; cf. State v. McFalls, 221 N.C. 22 , 18 S.E.2d 700 (1942).

20. People v. LaRocca, 68 Cal. App. 2d 652, 157 P.2d 378 (1945).

21. People v. Arbuthnot, 355 III. 577, 189 N.E. 888 (1934); see People v. Dempsey, 63 Cal. App. 751, 219 Pac. 1041 (1923). In Commonwealth v. Liebowitz, $132 \mathrm{~Pa}$. Super. 75, 17 A.2d 719 (1941), evidence that the stolen wallets were found along the course of defendant's flight from the scene of the crimes was sufficient to sustain a larceny conviction.

22. Letter from I. G. Cowan, Superintendent of Detectives, Atlanta, Ga., Dec. 10, 1954; letter from Frank W. Story, Chief of Police, Cleveland, Ohio, Feb. 24, 1955.

23. Letter from Michael J. Godfrey, Chief of Police, Hartford, Conn., Nov. 18, 1954; letter from H. V. Branch, Inspector of Detectives, Jacksonville, Fla., Nov. 2, 1954; letter from O. C. Beynon, Inspector of Detectives, Tampa, Fla., Jan. 20, 1955 ; letter from Jim Purcell, Jr., Chief of Police, Portland, Ore., Oct. 12, 1954. 
he may be unavailable or unwilling to remain for trial. ${ }^{24}$ Other pickpockets escape conviction because their neat, respectable appearance supports their denial of guilt or complicity. ${ }^{25}$ This result may be mitigated by introducing evidence of previous convictions as part of the prosecution's case to support the evidence identifying the thief. ${ }^{26}$ Nonetheless, it is apparent that the larceny statutes are generally inadequate to meet the pickpocket type of larceny because the special manner in which pickpockets operate requires superior police skill to detect the crime.

One possible method of minimizing the difficulty of proving larceny against a pickpocket is by increasing the number of specially trained squads. Reports by law enforcement officials indicated that these squads successfully reduce the incidence of pickpocketing, ${ }^{27}$ and it has been reported that the trained police detective will more readily notice the pickpocket at work and will be able to give credible evidence of the larceny. ${ }^{272}$ Specially trained police become familiar with the faces of known pickpockets and can recognize their modus operandi. ${ }^{28}$ Despite the transient nature of pickpockets, it has been demonstrated that interchange of photographs and information between police departments can prepare law enforcement officials for the arrival and apprehension of known pickpockets. ${ }^{29}$ Such officers are stationed at sporting events, parades, bus stops, hotel lobbies and railroad stations where pickpockets are most likely to operate, ${ }^{30}$ and will arrest while the theft is being perpetrated or immediately thereafter. ${ }^{31}$ In fact, it has been reported that word travels fast among the pickpocket fraternity and that pickpockets generally avoid localities where the special police are actively engaged in suppressing this type of crime. ${ }^{32}$

24. Letter from O. C. Beynon, Inspector of Detectives, Tampa, Fla., Jan. 20, 1955; memorandum from Police Detective Lieutenant Bert Hawkins, Louisville, Ky., Feb. 9, 1955.

25. Hapgood, The Autobiography of a Thief 40 (1903).

26. See Peoples v. James, 40 Cal. App. 2d 740, 105 P.2d 947 (1940).

27. Letter from Walter F. Johnson, Chief of Police, by James E. Childers, Division Chief, Denver, Colo., Oct. 28, 1954; letter from Howard O. Young, Chief of Police, New Haven, Conn., Oct. 13, 1954; letter from Peter Stewart, Capt. Deputy Chief, Miami Beach, Fla., Jan. 29, 1955 ; letter from Information Officer for Joseph L. Scheuering, Department of Police, New Orieans, La.; letter from Richard A. Dougherty, Deputy Commissioner Community Relations, New York, N.Y., Nov. 22, 1954.

27a. Telephone interview with Captain Richard T. Doyle, Philadelphia Police Force, Dec. 12, 1955.

28. Letter from Peter Stewart, Capt. Deputy Chief, Miami Beach, Fla, Jan. 29, 1955; letter from Information Officer for Joseph L. Scheuering, Department of Police, New Orleans, La.; letter from Richard A. Dougherty, Deputy Commissioner Community Relations, New York, N. Y., Nov. 22, 1954.

29. Letter from Howard O. Young, Chief of Police, New Haven, Conn., Oct. 13, 1954; letter from Peter Stewart, Capt. Deputy Chief, Miami Beach, Fla., Jan. 29,1955 ; letter from Richard A. Dougherty, Deputy Commissioner Community Re-
lations, New York, N. Y., Nov. 22, 1954.

30. See note 23 supra.

31. Letter from Richard A. Dougherty, Deputy Commissioner Community Relations, New York, N. Y., Nov. 22, 1954.

32. Letter from Howard $O$. Young, Chief of Police, New Haven, Conn., Oct. 13, 1954 ; letter from Richard A. Dougherty, Deputy Commissioner Community Relations, New York, N. Y., Nov. 22, 1954. 
Although some jurisdictions using trained detectives who watch suspected pickpockets and arrest them as soon as the theft is perpetrated report successful larceny prosecutions, increased detection by skilled personnel cannot provide the only answer to the problem of convicting the pickpocket. Even if the trained detective moves swiftly, it is often difficult for him to see the actual taking from the victim's pocket or to catch the thief with the stolen article in his possession. ${ }^{33}$ Thus, many law enforcement officials who have been faced with the inadequacy of the larceny statute to meet the pickpocket form of larceny, have turned to other statutes which require a lesser or different burden of proof.

\section{Vagrancy}

According to the survey of law enforcement officials made for this Note, the most frequently used criminal statutes under which the suspected pickpockets are prosecuted are: vagrancy, known-thief, criminal registration and jostling. Many jurisdictions have enacted more than one of this type of statute, ${ }^{34}$ thereby leaving a choice of which to use in any particular case to the prosecuting official.

Before considering the appropriateness of each of these types of crime to the problem of pickpocketing, it is well to note the similarity of characteristics among them. They fall into the general classification of petty offenses and hence ordinarily do not authorize the imposition of major penalties. ${ }^{35}$ Because of their petty nature, ${ }^{36}$ they are grist for the mill of the justice of peace or magistrate, and the accused is usually not afforded a right to a jury trial. ${ }^{37}$ Furthermore, this type of conviction only rarely appears as the subject of an appeal to a higher court. ${ }^{38}$ As a result the administration of these crimes is placed in the hands of the police, in the first instance, with the primary check on arbitrary enforcement being in the courts of justices of the peace and magistrates, practically all of whom are unversed in any formal legal education.

33. Letter from O. C. Beynon, Inspector of Detectives, Tampa, Fla., Jan. 20, 1955; letter from I. G. Cowan, Superintendent of Detectives, Atlanta, Ga., Dec. 10, 1954.

34. E.g., N.Y. Code Crim. Proc. $\$ 887$ (vagrancy) ; N.Y. Code Crm. Proc. \$ 898-a (professional thief); N.Y. PEN. LAW \$722(6) (jostling).

35. See notes $44-47,78,84,87,88$ infra.

36. Vagrancy was triable summarily at common law as a "petty offense." State v. Glenn, $54 \mathrm{Md}$. 572, 600-05 (1880).

37. See, e.g., PA. Stat. Ann. tit. 18, $\$ 4821$ (Purdon 1945) ; N.Y. Code Crim. Proc. \$898-a. There is no constitutional requirement of jury trial for conviction as a vagrant, State v. Glenn, supra note 36; People v. Phillips, 1 Park Cr. 95 (N.Y. 1847 ), or as a known-thief, Byers \& Davis v. Commonwealth, $42 \mathrm{~Pa} .89$ (1862), because the grant of jury trial in state constitutions requires trial by jury only for offenses necessitating a jury trial before the enactment of the state constitutions. State $v$. Maier, 13 N.J. 235, 99 A.2d 21 (1953); People v. One 1941 Chevrolet Coupe, 37 Cal. 2d 283, 286-87, 231 P.2d 832, 835 (1951). A provision granting a right to de novo jury trial on appeal from the summary conviction sufficiently satisfies the requirement of jury trial. Des Moines v. Pugh, 231 Iowa 1283, 1289-90, 2 N.W.2d $754,757-58$ (1942) ; City of Bellingham v. Hite, 37 Wash. 2d 652, 657-58, 225 P.2d 895,899 (1950).

38. Note, 59 Yale L.J. 1351, 1357 n.21 (1950). 
According to many officials who were questioned for this study the vagrancy statute or ordinance is used regularly to control pickpocketing where sufficient evidence cannot be or is not developed to establish a larceny charge. The elements which constitute vagrancy vary widely among the states and are often very similar to, or are combined with, the requirements for conviction under known-thief statutes. However, the basic element in the known-thief statutes, a known pickpocket being in a specified place for an unlawful purpose, is distinguishable from the requirement of loitering and idleness which characterizes many vagrancy statutes. Pickpockets are generally prosecuted under one of the following definitions of vagrancy: living in idleness or without employment and having no visible means of support, ${ }^{39}$ or being a pickpocket having no visible or lawful means of support when found loitering around a public gathering or assembly. ${ }^{40}$

These elements are sufficiently vague to permit conviction of the pickpocket as a vagrant with little difficulty. While some prosecutions for "loitering" are impeded because pickpockets often provide themselves with a lawful reason for being at a place, such as buying a bus ticket when operating at bus stops, ${ }^{41}$ this device is not always successful in avoiding convictions. ${ }^{42}$ The defendant's possession of money is not considered proof of visible means of support. ${ }^{43}$

Under the vagrancy statutes, pickpockets are sentenced to imprisonment for 30 days ${ }^{44}$ to one year ${ }^{45}$ and fines ranging from $\$ 3^{46}$ to $\$ 1000 ;{ }^{47}$ the judiciary often assess the maximum penalties. ${ }^{48}$ In some localities, the magistrate orders the pickpocket to leave town under threat of punishment for contempt of court ${ }^{49}$ or enforcement of the suspended sentence. ${ }^{50}$ This is generally an illegal form of sentence ${ }^{51}$ and its imposition is probably an

39. Ala. Code ANn. tit. 14, \$437 (1940) ; ARIz. Code ANn. \$43-5901 (1939); ARK. Stat. ANN. \$ 41-4301 (1947).

40. Cal. Pen. Code $\$ 647$ (4) (Deering 1949); D.C. Code Ann. $\$ 22-3302(1)$ (1951); Ill. ANN. Stat. c. 38, \$578 (Smith-Hurd 1935).

41. Letter from W. H. Parker, Chief of Police, by S. H. Sheldon, Capt. Public Information Division, Los Angeles, Calif., Nov. 19, 1954.

42. Burns v. District of Columbia, 34 A.2d 714 (D.C. Mun. App. 1943).

43. 'Ibid.; People v. Cramer, 139 Misc. 545, 547, 247 N.Y. Supp. 821, 824 (Ct. Sp. Sess. 1930).

44. N.D. REv. CODE $\$ 12-4204$ (1943).

45. ConN. Gen. Stat. \$8639 (1949).

46. N.M. Stat. ANN. \$40-48-2 (1953).

47. Conn. Gen. Stat. $\$ 8639$ (1949).

48. Letter from Howard O. Young, Chief of Police, New Haven, Conn., Oct. 13, 1954; see letter from Walter $F$. Johnson, Chief of Police, by James $E$. Childers, Division Chief, Denver, Colo., Oct. 28, 1954; letter from H. V. Branch, Inspector of Detectives, Jacksonville, Fla., Nov. 2, 1954.

49. Letter from John E. Ambuhl, Chief of Police, by Noel Jones, Inspector of Detectives, Indianapolis, Ind., Nov. 9, 1954.

50. Letter from Jim Purcell, Jr., Chief of Police, Portland, Ore., Oct. 12, 1954.

51. In re Scarborough, 76 Cal. App. 2d 648, 173 P.2d 825 (1946) ; People v. Baum, 251 Mich. 187, 231 N.W. 95 (1930) ; State v. Doughtie, 237 N.C. 368, 74 S.E.2d 922 (1953); State v. Baker, 58 S.C. 111, 36 S.E. 501 (1900). 
unconstitutional infringement of personal liberty, ${ }^{52}$ but its use is virtually unchallenged. Such a fact stands as mute evidence of the lack of effective judicial review of this type of proceeding by the highest courts of the states.

\section{Known-Thief Lazes}

Professional criminal and known-thief statutes and ordinances, like the vagrancy statutes just discussed, are often used when there is insufficient evidence for a larceny conviction, ${ }^{53}$ and are also used by the police to incarcerate persons who are engaging in suspicious activities which indicate a strong possibility that a theft will soon be attempted. ${ }^{54}$ In general, the three elements of criminality under these laws are: (1) previous conviction of larceny or pickpocketing ${ }^{55}$ or reputation as a pickpocket, (2) presence at a listed public place, (3) for an unlawful purpose. The definition of each element may differ with the jurisdiction.

The variations among the states as to the first element of the offense are manifold. Initially there is the obvious distinction between the objective requirement that the accused have prior convictions, which is provable by recourse to the records of the state, ${ }^{56}$ and the intangible factor of reputation when the only requirement is that the defendant be known to be a pickpocket.57 While conviction as a pickpocket indicates that the defend-

52. In Edwards v. California, 314 U.S. 160 (1941), the Supreme Court invalidated a state statute, which forbade bringing indigent persons into the state, on the theory that this violated the interstate commerce clause. In the course of the opinion, the majority said the state can not ". . . isolate itself from difficulties common to all of them by restraining the transportation of persons and property across its borders." Id. at 173. The concurring opinion was based on the belief that the right to move freely from state to state is an incident of national citizenship protected against state interference by the privileges and immunities clause. Id. at 178. In Corfield v. Coryell, 6 Fed. Cas. 546, No. 3230 (C.C.E.D. Pa. 1823), ". . . the right of a citizen of one State to pass through, or to reside in any other state ..." was listed as one of the protected privileges and immunities. Id. at 552. State legislation taxing people leaving a state was held unconstitutional on the theory that all citizens had a right to resort to the seat of the Government to claim justice and this right to travel to the Government cannot be infringed by a state over whose territory the citizen must pass. Crandall v. Nevada, 73 U.S. (6 Wall.) 35 (1867).

53. Letter from Richard A. Dougherty, Deputy Commissioner Community Relations, New York, N. Y., Nov. 22, 1954; letter from O. L. Blough, Chief of Police, Harrisburg, Pa., Nov. 12, 1954.

54. Letter from Fred G. McCartney, Commissioner of Police, Lancaster, $\mathrm{Pa}$, March 14, 1955.

55. Conviction of jostling is not a conviction as a pickpocket or thief. Letter from Richard A. Dougherty, Deputy Commissioner Community Relations, New York, N. Y., Nov. 22, 1954.

56. Letter from Richard A. Dougherty, Deputy Commissioner Community Relations, New York, N. Y., Nov. 22, 1954.

57. There is a strong possibility that many of the statutes defining criminality in terms of reputation violate the due process clause on the ground that they are arbitrary and unreasonable in punishing a defendant for what he is supposed to be regardless of what he actually is. See People v. Alterie, 356 Ill. $307,312,190 \mathrm{~N}$.E. 305, 307 (1934) ; People v. Belcastro, 356 Ill. 144, 150, 190 N.E. 301, 304 (1934). Such statutes have been held unreasonable restrictions on the right to personal liberty guaranteed by the Constitution. City v. Royce, 128 Mo. 541 (1895). However, a statute coupling a provision of no visible income with the association requirement was upheld. Morgan v. Virginia, 168 Va. 731, 191 S.E. 791 (1937). Some statutes 
ant is known to be such, the legislatures have not always been specific as to what other basis is adequate to make one "known to be a pickpocket." 58 The vagueness of this element is illustrated by some of the language found in these statutes: "known to be a pickpocket," 59 "known or reputed to be a pickpocket," 60 "any evidence, either of facts or reputation, proving that such person is habitually and by practice a thief or pickpocket, shall be sufficient for his conviction if satisfactorily establishing the fact to the court or jury."61 Some say merely that the defendant must be ". . . proven to the satisfaction of the magistrate before whom he is brought, to be a common thief," 62 or the extraordinarily loose requirement that he simply be ". . charged before a magistrate with being a professional thief." 63

The places at which attendance by known thieves is prohibited likewise differ. In addition to specifically enumerated places, e.g., railroad depot, banking institution, place of amusement or crowded thoroughfare, there is usually a clause of general coverage such as "at any public gathering or assembly." 64 One statute has done away with enumeration entirely, and allows conviction of thieves found in "any place." 65 Occasionally ordinances have been passed to prohibit attendance of pickpockets at special events, e.g., the grounds of the 1939 New York World's Fair. ${ }^{66}$

Various formulations of the third element of known-thief laws include that the accused be unable to give a good account of himself, ${ }^{67}$ have an illegal purpose, ${ }^{68}$ be acting in a suspicious manner, ${ }^{69}$ or have no means of support. $^{70}$

Reports compiled from the replies of enforcement officials indicate that in practice the requirement of proof under these laws is not very stringent,

make reputation or association prima facie evidence of an offense. See, e.g., N.J. StaT. ANN. §2A: 170-1 (1953) ; N.Y. PEN. LAW \$ $722(11),(12)$. The test of the validity of these statutes under the due process clause is that there must be some rational connection between the fact proved, i.e., reputation or association, and the ultimate fact presumed, i.e., commission of the offense, and that the inference shall not be so unreasonable as to be purely arbitrary. See Mobile J. \& K. R.R. v. Turnipseed, 219 U.S. 35, 43 (1910).

58. However, some statutes do require that the accused be known as a thief by prior conviction, N.Y. CODE CrIM. Proc. \$898-2, and conviction or confession, Cal. Pen. Code Ann. \$647(4) (Deering 1949); D.C. Code Ann. \$22-3302 (1951).

59. Mass. AnN. Laws c. $272, \S 68$ (1933); R.I. Gen. Laws c. $610, \S 39$ (1938).

60. Conn. Gen. Stat. $\$ 8639$ (1953).

61. MD. ANN. CoDE art. 27, $\$ 630$ (1951).

62. N.J. Stat. ANN. §2A:170-2 (1953).

63. Pa. Stat. Ann. tit. 18, §4821 (Purdon 1945).

64. E.g., Cal. Pen. Code Ann. \$647(4) (Deering 1949); Conn. Gen. Stat. $\S 8639$ (1953) ; D.C. Code ANn. \$22-3302 (1951); N.Y. Code CrMM. Proc. § 898-a; R.I. GEN. LAws c. $610, \S 39$ (1938).

65. Pa. Stat. Ann. tit. 18, §4821 (Purdon 1945).

66. See N.Y. Times, April 19, 1939, p. 16 col. 1.

67. D.C. Code ANN. \$22-3302 (1951).

68. N.J. Rev. Stat. \$2A:170-1 (1953); N.Y. Code CrIM. Proc. §898-a; Pa. Stat. Ann. tit. 18, $\$ 4821$ (Purdon 1945).

69. Mass. Ann. Laws c. $272, \S 68$ (1933).

70. Cal. Pen. Code Ann. $\$ 647$ (4) (Deering 1949); Conn. Gen. Stat. \$ 8639 (1953); R.I. GEN. LAwS c. 610, \$39 (1938); UTAH CODE ANN. \$76-61-1(4) (1953). 
and convictions are readily obtained. Previous conviction is shown by identification of the defendant as the person previously convicted, and certified copies of the court records. ${ }^{71}$ Proof of reputation may require officers who previously arrested the defendant, as reflected by his official arrest record, to testify at the court hearings. ${ }^{72}$ Presence at the place enumerated by the statute ${ }^{73}$ is proved by the arresting officer's testimony. ${ }^{74}$ Unlawful purpose is shown by circumstantial evidence such as repeated boarding of crowded buses, riding a short distance and returning to the bus depot. ${ }^{75}$ If a pickpocket who has been previously convicted is present in a large crowd, this is considered evidence of unlawful purpose by some law enforcement officials. ${ }^{76}$ One jurisdiction even reported that presence at places where crowds gather by one with a reputation as a known-thief establishes the requisite unlawful purpose. ${ }^{77}$ Notwithstanding the relative ease with which convictions may be obtained under these statutes, penalties may be as high as five years imprisonment and one thousand dollars fine. ${ }^{78}$

However, the requirements that are imposed, even under the same statutory language, are apparently not uniformly interpreted in different localities. For example, to prove the element that the defendant was a "professional thief" or "professional pickpocket" under a Pennsylvania statute, ${ }^{79}$ law enforcement officials of several cities reported that they believed reputation as a thief or pickpocket was enough; ${ }^{80}$ others required either suspicious acts or attendance at a public assembly as well $;^{81}$ and some indicated that proof of a previous conviction was necessary. ${ }^{82}$

71. Letter from Richard A. Dougherty, Deputy Commissioner Community Relations, New York, N.Y., Nov. 22, 1954.

72. Letter from Fred G. McCartney, Commissioner of Police, Lancaster, Pa., March 14, 1955.

73. When a pickpocket who was operating at a meeting held in a courthouse was convicted under a statute which specified presence must be at a "place of public amusement," the conviction was reversed because the place was not within the meaning of the statute. Commonwealth v. Roth, $136 \mathrm{~Pa}$. Super. 301 (1939).

74. Ietter from Fred G. McCartney, Commissioner of Police, Lancaster, Pa., March 14, 1955.

75. Letter from Richard A. Dougherty, Deputy Commissioner Community Relations, New York, N.Y., Nov. 22, 1954.

76. Letter from William Gillespie, Lieutenant of Detectives, Upper Darby, Pa., Dec. 11, 1954.

77. Letter from Gorman J. Christine, Chief of Police, York, Pa., Dec. 1, 1954.

78. MD. Ann. Code art. 27, $\$ 630$ (1951).

79. PA. Stat. ANN. tit. 18, §4821 (Purdon 1945).

80. Letter from Paul J. McKinney, Captain of Detectives, Chester, Pa., March 8, 1955; letter from Anthony Hutskow, Detective Technician, McKeesport, Pa., Nov. 16, 1954.

81. Letter from Fred G. McCartney, Commissioner of Police, Lancaster, Pa, March 14, 1955; letter from Gorman J. Christine, Chief of Police, York, Pa., Dec. $1,1954$.

82. Letter from O. L. Blough, Chief of Police, Harrisburg, Pa., Nov. 12, 1954; letter from William Gillespie, Lieutenant of Detectives, Upper Darby, Pa., Dec. 11, 1954. 


\section{Criminal Registration Ordinances}

A few jurisdictions reported that pickpockets sometimes are arrested for failure to comply with the municipal criminal registration ordinance. 83 These generally provide that convicted criminals who come into the municipality and fail to register with the police on arrival may be arrested and subjected to penalties of up to six months in jail plus a fine of five hundred dollars. ${ }^{84}$ These laws give a wide discretion to police officials to control the movements of pickpockets so long as there is at least one conviction of a crime (not necessarily pickpocketing) on their records.

\section{Jostling or Disorderly Conduct}

The last type of law which replies to questionnaires indicated is fairly widely used to penalize pickpockets who cannot be convicted under the applicable larceny statute is the disorderly conduct or jostling statute or ordinance. ${ }^{85}$ The elements of the offense are very simple; a person is guilty if it is found that he was unnecessarily pushing, crowding or jostling another. ${ }^{86}$ Penalties run as high as for violations of criminal registration laws: up to six months imprisonment ${ }^{87}$ and five hundred dollars fine. ${ }^{88}$ Sometimes the pickpocket is released upon his posting of the maximum bond, which is often forfeited because the accused leaves the locality to ply his trade elsewhere. ${ }^{89}$ Some cities reported a high degree of success from the use of the jostling laws to reduce the incidence of pickpocketing.90 New York City, for example, made more arrests for jostling than all other applicable statutes together and it is reported that this is operating effectively.91

\section{Evaluation}

From the discussion above, it appears that an extraordinary situation exists in the approach of the criminal law, and the officials charged with its administration, to the problem of larceny by pickpocketing. The description of the crime and the criminal, and the character of the statutes or ordinances under which offenders are prosecuted, together with reports of

83. Letter from H. G. Howard, Chief of Detectives, Miami, Fla., Dec. 27, 1954; letter from R. H. Lee, Lieutenant of Detectives, St. Petersburg, Fla.; letter from O. C. Beynon, Inspector of Detectives, Tampa, Fla., Jan. 20, 1955; letter from L. R. Gruson, Reno, Nev., Feb. 23, 1955.

84. Note, 103 U. PA. L. Rev. 60, 79 (1954).

85. Letter from H. G. Howard, Chief of Detectives, Miami, Fla., Dec. 15, 1954; letter from Richard A. Dougherty, Deputy Commissioner Community Relations, New York, N. Y., November 22, 1954.

86. See N.Y. Pen. LaW $\S 722(6)$.

87. N.Y. PEN. LAW $\$ 723$.

88. Code of the City of Miami, Fla., c. $35, \S 7$.

89. Letter from H. G. Howard, Chief of Detectives, Miami, Fla., Dec. 15, 1954. $13,1954$.

90. Letter from Howard O. Young, Chief of Police, New Haven, Conn., Oct.

91. Letter from Richard A. Dougherty, Deputy Commissioner Community Relations, New York, N.Y., Nov. 22, 1954. 
enforcement officials, seem to call for further inquiry into the question of whether existing law is effectively and properly dealing with the problem.

The major proposition that is revealed by this picture is that pickpocketing is not being controlled as an offense of larceny; rather the alleged offenders are prosecuted under laws that bear little or no relation to the offense for which they actually were arrested. The criminal registration ordinances are-probably the-mest extreme illustration of an offense whose definition contains no elements that would distinguish pickpockets from non-thieves. From the time that a person enters the municipal limits and fails to register the fact that he is a convict, he is subject to arrest and prosecution. In terms of pickpocketing, he can be picked up by the police on the slightest hint that he has already committed or attempted to commit the act, or is about to do so. The flimsiness of the evidence on the suspected larceny is, of course, never brought out because it is not at all relevant to the crime for which the defendant will be charged.

The situation is not much different when the police use instead the vagrancy or known-thief laws. The special attribute of these laws is that they do away with any necessity of proving a criminal act; they make it a crime to be the described undesirable person. ${ }^{92}$ It is true that some of the laws refer to the crime of pickpocketing by defining vagrancy in terms of a person, known or reputed to be a pickpocket, in a specified place but the relationship to pickpocketing is purely verbal; a person charged under these laws is not accused of picking someone's pocket. His demeanor and comportment were deemed sufficiently suspicious to warrant his arrest, and it develops that his record includes a conviction of pickpocketing.

On the other hand, the jostling statutes and ordinances may be argued to have a closer relationship to the problem of larceny from the person. They focus on an act, which may be said to give rise to a reasonable inference that a pocket has been or is about to be picked. However, a moment's reflection reveals that they may largely be weapons in the hands of the police to use as they see fit. At least in places where throngs of people congregate, the selection of the criminal in the crowd on the basis of the fact that he was pushing or crowding another is virtually impossible. Thus we leave it to the police to identify each suspect on factors not stated as elements of the offense.

In addition to this observation on the basic relationship of the laws used and the type of offense, other facts appear which are relevant to the question of the adequacy of present law. Most police officials report that pickpocketing is being controlled successfully under the existing statutory pattern. They did not indicate the desire or need for supplementation or modification. A countervailing implication may be drawn, however, from the unusually high recidivist rate found among pickpockets. ${ }^{93}$ This might

92. See the excellent discussion of status crimes in Lacey, Vagrancy and Other Crimes of Personal Condition, 66 HARv. L. Rev. 1203 (1953).

93. Pickpockets have been arrested for thefts committed while on bail awaiting trial on charge of pickpocketing. Letter from Richard A. Dougherty, Deputy Commissioner New York, N.Y., Nov. 22, 1954. 
indicate that the risk of being caught and prosecuted for a petty offense with its minimal punishment is outweighed by the potential gain to be obtained by employing the art of picking pockets. ${ }^{94}$ In the traditional treatment of larceny by the criminal law, there is a classification of offenses and offenders according to the amount of money or the value of the property stolen. This pattern is not possible in the case of pickpockets who are prosecuted as vagrants or for similar offenses. No gradation is made on the standard of the amount stolen, since the accused is not being tried for stealing. The inference that the penalties imposed on pickpockets are inadequate to deter them from engaging in the practice is weakened, however, by the observation of some people that the number of skilled pickpockets is declining. ${ }^{95}$ This may be the result of the fact that it is no longer profitable in the long run to be a pickpocket, even though the possible period of incarceration for any one conviction is not very great.

It is difficult to draw conclusions on the basis of these observations of the application of criminal law to pickpockets. In a theoretical setting, the prosecution of larceny under laws unrelated to larceny is seriously questionable. Nevertheless, no matter how distasteful any situation is, it should not be condemned unless there is a better solution to the problem. There are not many "better" solutions for the problem of pickpocketing. The more obvious one is to train special police in techniques of pickpocketing to the extent that they can detect the criminal in action and come forward with sufficient testimonial evidence to convict the pickpocket of larceny. Whether or not such a plan is practicable is unknown. An alternate approach is to adopt a new provision in the criminal code which would set forth a larceny-type crime defined in terms of elements which are reasonably capable of proof and which, at the same time, are specific enough to distinguish the criminal and the act which the legislature intends to punish. ${ }^{96}$ Even assuming that such a statute could be drafted, there remains the fact that law enforcement officials are now using, and may continue to use, vagrancy-type crimes to control pickpockets. There does not appear to be any feasible method of requiring the prosecution of pickpockets of a larceny rather than a vagrancy offense. However, both suggestions mentioned seem more desirable than the present approach which places expediency above the principle that persons shall be convicted for committing the act which the legislature has deemed anti-social rather than under vague omni-

94. Pickpockets view conviction as an occupational hazard. See Martinez, Secrets of a Pickpocket Detective, Saturday Evening Post, Oct. 21, 1950, p. 162.

95. Letter from Carl Ousley, Jr., Assistant Commonwealth's Attorney, Louisville, Ky., Feb. 10, 1955; letter from Robert Reilly, Chief of Police, Norristown, Pa., Oct. 26, 1954.

96. Cf. N.Y. PEN. LAw \$722(6) (Supp. 1955) providing that a person is guilty of disorderly conduct who: "Interferes with any person in any place by jostling against such person or unnecessarily crowding him or by placing a hand in the proximity of such person's pocket, pocketbook or handbag; or who stations himself in any place, or follows or accosts any person for the purpose of obtaining money or other property from said person by any trick, artifice, swindle, confidence game, or in any other illegal manner." (Emphasis added.) 
bus statutes which permit conviction of persons whom enforcement officials deem undesirable. While it is recognized that in isolated instances lack of proof for one offense may dictate prosecution for another unrelated crime, this should be used only in special circumstances and should not be considered as an acceptable solution to the problem of successful conviction of an entire class of offenders. 